DE

M E D I C I N A

T R O P I C A L

$\mathrm{DE}$

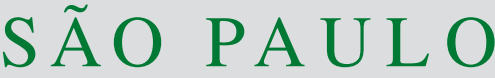

JOURNAL OF THE SÃO PAULO INSTITUTE OF TROPICAL MEDICINE

(1) Universidade Estadual de Maringá, Programa de Pós-Graduação em Ciências da Saúde, Maringá, Paraná, Brazil

(2) Universidade Federal do Paraná, Departamento de Patologia Básica, Laboratório de Parasitologia Molecular, Curitiba, Paraná, Brazil

(3) Universidade Positivo, Curitiba, Paraná, Brazil

(4) Universidade Federal do Paraná,

Programa de Pós-Graduação em Microbiologia, Parasitologia e Patologia, Curitiba, Paraná, Brazi

${ }^{(5)}$ Núcleo de Entomologia de Porto Rico, Porto Rico, Paraná, Brazil

Correspondence to: Kárin Rosi ReinholdCastro.

Universidade Estadual de Maringá,

Programa de Pós-Graduação em Ciências da Saúde, Av. Colombo, 5790, CEP 87020900, Maringá, PR, Brazil.

E-mail: karindecastro@yahoo.com.br

Received: 31 August 2015

Accepted: 26 September 2016

\section{Genetic variability of populations of Nyssomyia neivai in the Northern State of Paraná, Brazil}

Jaqueline de Carvalho Gasparotto', Magda Clara Vieira da Costa-Ribeiro², Vanete Thomaz-Soccol ${ }^{3}$, Sandra Mara Rodrigues da Silva Liebel ${ }^{4}$, Herintha Coeto Neitzke-Abreu'1, Kárin Rosi Reinhold-Castro', Edilson Colhera Cristovão ${ }^{5}$, Ueslei Teodoro ${ }^{1}$

\section{ABSTRACT}

The genetic study of sandfly populations needs to be further explored given the importance of these insects for public health. Were sequenced the NDH4 mitochondrial gene from populations of Nyssomyia neivai from Doutor Camargo, Lobato, Japira, and Porto Rico, municipalities in the State of Paraná, Brazil, to understand the genetic structure and gene flow. Eighty specimens of Ny. Neivai were sequenced, 20 from each municipality, and 269 base pairs were obtained. A total of 27 haplotypes and 28 polymorphic sites were found, along with a haplotypic diversity of 0.80696 and a nucleotide diversity of 0.00567 . Haplotype H5, with 33 specimens, was the most common among the four populations. Only haplotypes H5 and $\mathrm{H} 7$ were present in all four populations. The population from Doutor Camargo showed the highest genetic diversity, and only this population shared haplotypes with those from the other municipalities. The highest number of haplotypes was sheared with Lobato which also had the highest number of unique haplotypes. This probably occurred because of constant anthropic changes that happened in the environment during the first half of the twentieth century, mainly after 1998. There was no significant correlation between genetic and geographical distances regarding these populations. However, the highest genetic and geographical distances, and the lowest gene flow were observed between Japira and Porto Rico. Geographical distance is a possible barrier between these municipalities through the blocking of haplotype sharing.

KEYWORDS: Sandflies. Lutzomyia. mtDNA. Phylogeny. Genetic polymorphism.

\section{INTRODUCTION}

The importance of leishmaniasis for public health is expressed by its wide distribution in 98 countries $^{1}$. The incidence of cutaneous leishmaniasis (CL) in Latin America is high, especially in Brazil, where 635,399 cases were detected from 1990 to $2013^{2}$. Of these cases, $13,889(2.2 \%)$ were reported in the South of the country, especially in the State of Paraná (94.9\% of the total cases in the South) ${ }^{2}$.

Worldwide, 988 species of sandflies have been described (961 current and 27 fossil). American species comprise 529 of these, of which 512 are current and 17 are fossil ${ }^{3}$. In Brazil, 19 species are suspected or implicated in the transmission of Leishmania to humans ${ }^{4}$. Among the small number of species of importance for the epidemiology of CL in Brazil, Nyssomyia whitmani (Antunes and Coutinho) and Nyssomyia neivai (Pinto) are prominent, and both species are widely distributed in Paraná ${ }^{5-8}$. In this state, Ny. neivai occurs in several ecotopes in peridomiciles, especially in domestic-animal shelters ${ }^{5-8}$. 
Ny. neivai and Ny. intermedia belong to the Nyssomyia intermedia complex, and can be morphologically differentiated by their spermathecae ${ }^{9}$. Ny. neivai is found in colder and drier areas in natural environments, and easily adapts to human-impacted environments ${ }^{10-13}$. This species is present on the coast and interior of several States of Brazil, including Western São Paulo, Paraná, Southern and Western Minas Gerais, Southern Goiás and Southern Pará, as well as in Argentina, Bolivia and Paraguay ${ }^{14}$.

Research on molecular markers has been used to evaluate sandfly polymorphism. Investigations on the genetic structure of populations of these insects are necessary for the understanding of the species dispersal patterns ${ }^{15}$ and for the development of control strategies. Mitochondrial DNA (mtDNA) has often been used as a molecular marker in the study of genetic variability of populations because it is maternally inherited and does not recombine. Thus, it is possible to study the genetic variability among populations of a certain species and estimate the rates of gene flow among populations by using a fragment of the mitochondrial NADH dehydrogenase subunit 4 (NDH4) ${ }^{16,17}$.

Genetic variability is high among sandfly species. $N y$. intermedia shows a greater genetic diversity in the wild than in domestic environments ${ }^{18,19}$. Souza et al. ${ }^{20}$ observed that Ny. whitmani has a high polymorphism and this is associated with the species' adaptability to different regions.

Studies of the genetics of sandfly populations in the Americas have been conducted with populations of $L u$. longipalpis, Lutzomyia cruzi, $N y$. intermedia, $N y$. whitmani and $N y$. neivai in Central and South America, and have revealed the existence of extensive haplotype diversity in these populations ${ }^{15,18-27}$. In the Old World, studies of population genetics have given particular attention to Phlebotomus papatasi ${ }^{28-30}$.

In view of the importance of sandflies for CL epidemiology, studies to evaluate these insects' polymorphism with molecular markers are needed to extend the knowledge of the genetic variability and patterns of species dispersal in order to support further investigations about sandflies ecology. The importance of $N y$. neivai for CL epidemiology aroused our interest in studying the genetic variability in populations of this sandfly species.

\section{MATERIAL AND METHODS}

\section{Sample sites}

Collections of Ny. neivai were made in four municipalities (Doutor Camargo, Japira, Lobato and Porto Rico) (Figure 1). The climate is mesothermal humid subtropical, with more rainfall in summer and a dry winter, and mean

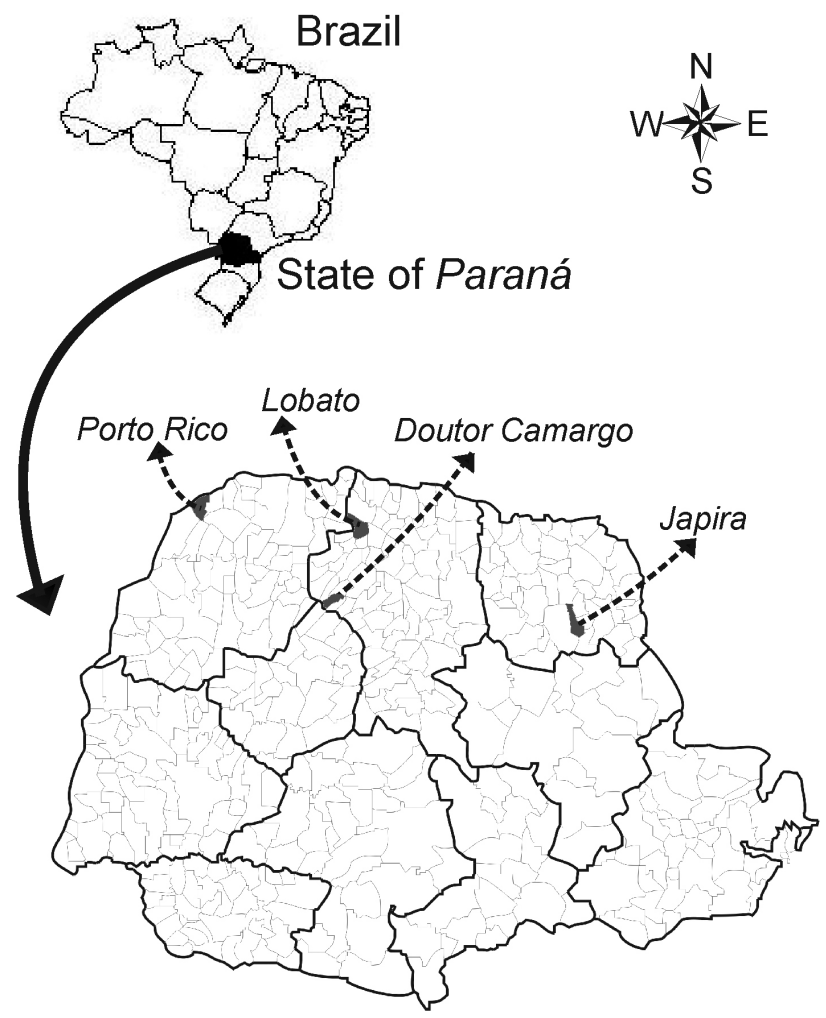

Figure 1 - Geographical location of municipalities of Doutor Camargo, Japira, Lobato, and Porto Rico, where the collection of sandflies was made, State of Paraná, Brazil.

temperatures above $22{ }^{\circ} \mathrm{C}$ in summer and below $18{ }^{\circ} \mathrm{C}$ in winter. The native vegetation is composed of semideciduous forests. The criteria for selecting the municipalities were geographical distance, environmental factors, and reported LT cases.

Doutor Camargo municipality is located in the North Central Paraná Mesoregion (233' S and $52^{\circ} 13^{\prime} \mathrm{W}$ ), at $585 \mathrm{~m}$ above sea level and on the banks of the Ivai river. Sandflies were collected in a sheep shelter and a hen house in the Recanto Marista, a recreation area that covers 57.6 ha, of which 40.8 ha is occupied by an altered forest remnant that is still inhabited by birds and wild mammals.

Japira municipality is located in the North Pioneer

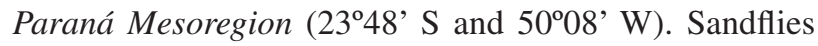
were collected in the locality of Estrelinha in a sheep shelter, pigsty, hen house, and in a guava tree located at a small and much-altered woodlot.

Lobato municipality is located in the North Central

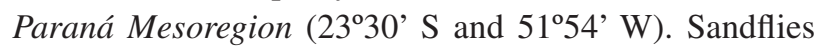
were collected on the porch of a residence and in a pigsty and a hen house on Barra Farm. The native vegetation of this municipality was replaced by permanent and temporary crops, although 700 ha of native forest remain on the farm.

Porto Rico municipality is located on the bank of the Paraná river, in the Northwest Paraná Mesoregion (2246' S 
and $\left.53^{\circ} 16^{\prime} \mathrm{W}\right)$. Sandflies were collected in a hen house and pigsty on Mutum Island, within the Environmental Protection Area (APA) of Islands and Lowlands of the Paraná river. This island belongs to Porto Rico municipality and is approximately $15 \mathrm{~km}$ long and 500 to $1,000 \mathrm{~m}_{\text {wide }}{ }^{31}$.

The areas of municipalities mentioned above have been occupied since the first half of the twentieth century, which are pioneering agricultural areas of Brazil. Since 1998, in Doutor Camargo municipality efforts to control these insects have been made, such as removing organic matter accumulated on the soil (decomposing leaves and fruits), cutting of trees and other vegetation, draining the soil to reduce moisture, and spraying buildings with an insecticide ${ }^{12}$. The monitoring of control measures has been periodic ${ }^{32}$, and changes in riparian vegetation have been favored by the occasional floods of the Ivai river.

\section{Collection and preparation of sandflies}

Specimens of Ny. neivai were collected with Falcão light traps installed in peridomicile areas, from 20:00 to 24:00 h on two or more consecutive days. The insects were killed with chloroform and placed in $1.5-\mathrm{mL}$ eppendorf microtubes containing $80 \%$ ethanol for conservation and later identification. Twenty females of $\mathrm{Ny}$. neivai from each municipality were identified, and preserved in individual 0.6-mL eppendorf microtubes containing $2.5 \mu \mathrm{L}$ of $80 \%$ ethanol until DNA extraction. The nomenclature of sandfly species follows Galati ${ }^{3}$.

\section{Extraction of DNA}

DNA was extracted according to Loxdale and Lushai ${ }^{32}$, with modifications. The ethanol-preserved insects were macerated with a plastic pestle in an eppendorf microtube with $200 \mu \mathrm{L}$ of a solution of $5 \%$ Chelex resin.

\section{Amplification of $\mathrm{NDH} 4$ gene}

PCR used $0.6 \mu \mathrm{M}$ of each primer (forward and reverse), $2 \mathrm{mM} \mathrm{MgCl}, 1$ x enzyme buffer, $0.6 \mathrm{mM}$ dNTP (Invitrogen), 1.5 U Taq DNA Polymerase (Invitrogen) and $2.0 \mu \mathrm{L}$ of the DNA sample, in a final volume of $25 \mu \mathrm{L}$. The primers were the same as those used by Gorrochotegui-Escalante $e t a l .^{33}$ and Paduan and Ribolla $^{34}$ and included the following sequences: $N D H 4$ forward (5'-TTGTGACCTAAGGCTCATGT-3') and NDH4 reverse (5'-CTATTCGGCTTCGTCCATGTT-3'). The amplification was carried out in a Bio-Rad iCycler thermocycler with 3 cycles at $94{ }^{\circ} \mathrm{C}$ for $2 \mathrm{~min}$., $37^{\circ} \mathrm{C}$ for $2 \mathrm{~min}$. and $72{ }^{\circ} \mathrm{C}$ for $1 \mathrm{~min}$. followed by 35 cycles at $94^{\circ} \mathrm{C}$ for $30 \mathrm{sec}$., $50{ }^{\circ} \mathrm{C}$ for $30 \mathrm{sec}$. and $72{ }^{\circ} \mathrm{C}$ for $1 \mathrm{~min}$.; and an extension at $72{ }^{\circ} \mathrm{C}$ for $5 \mathrm{~min}$. The PCR products were submitted to electrophoresis in $1 \%$ agarose gel with a 100 bp molecular marker. The gels were stained with ethidium bromide for $20 \mathrm{~min}$. and visualized in a Gibco BRL TFX35M UV transilluminator.

\section{Sequencing reaction}

All the PCR products were quantified by the Nanodrop 1000 spectrophotometer (Thermo Scientific). Samples were diluted at $25 \mathrm{ng} / \mu \mathrm{L}$ for sequencing, using $1 \mu \mathrm{L}$ of Big Dye Terminator $\mathrm{v} 3.1,0.4 \mathrm{x}$ dilution buffer, $1 \mathrm{mM}$ of each primer (forward and reverse), and $5 \mu \mathrm{L}$ of the sample, totaling $10 \mu \mathrm{L}$ of reaction volume. The reaction was carried out in a Bio-Rad iCycler thermocycler: 1 cycle at $96^{\circ} \mathrm{C}$ for $1 \mathrm{~min}$., followed by 25 cycles at $96^{\circ} \mathrm{C}$ for $10 \mathrm{sec}$., $56^{\circ} \mathrm{C}$ for $5 \mathrm{sec}$. and $60{ }^{\circ} \mathrm{C}$ for $4 \mathrm{~min}$., and stored at $4{ }^{\circ} \mathrm{C}$ overnight. The amplified product was purified and precipitated by adding $80 \mu \mathrm{L}$ of $65 \%$ isopropanol to each sample. These were incubated at room temperature for $20 \mathrm{~min}$. and centrifuged at $16,000 \mathrm{x}$ g for $25 \mathrm{~min}$. at $13{ }^{\circ} \mathrm{C}$, and the supernatant was discarded. Afterwards, to each sample $200 \mu \mathrm{L}$ of $70 \%$ ethanol were added and centrifuged at $16,000 \mathrm{x} \mathrm{g}$ for $10 \mathrm{~min}$. at $13{ }^{\circ} \mathrm{C}$. The supernatant was discarded and tubes were incubated at a temperature of $50{ }^{\circ} \mathrm{C}$ or at room temperature for approximately 24 hours. Next, each sample was re-suspended in $10 \mu \mathrm{L}$ of formamide, submitted to heat shock, and sequenced in an ABI 3130 automated sequencer (Applied Biosystems).

\section{Alignment of sequences}

Sense and anti-sense strand sequences of the $\mathrm{NDH} 4$ gene were examined in the Staden software package version $1.5^{35}$, which produced a consensus strand for each sample. The sequences were aligned using the Clustal X program version $1.83^{36}$.

\section{Data analysis}

Relationships between mtDNA haplotypes were evaluated and dendrograms were constructed using the Neighbor-Joining method by means of the 5.5-MEGA Molecular Evolutionary Genetics Analysis program ${ }^{37}$. $\mathrm{NDH} 4$ gene sequences of $\mathrm{Ny}$. whitmani, Pintomyia fischeri and Pintomyia pessoai were used as outgroups (CostaRibeiro, unpublished data).

The nucleotide sequences and frequencies of each haplotype (synonymous and non-synonymous regions), the mean number of nucleotide differences $(\mathrm{K})$, haplotype 
diversity (Hd), genetic distance, gene flow $^{38}$ and random evolution of $N y$. neivai were estimated using the DnaSP program, version $5^{39,40}$. The relationship between genetic haplotypes was evaluated using the Network program, version 4.6.10, based on the Median Joining method (Fluxus Technology Ltd.). The genetic distance (Fst) was analyzed using the formula $\mathrm{Fst}=1 / 2 \mathrm{Nm}+1$, and $\mathrm{Nm}=$ gene flow. The geographical distance between localities was determined using the Google Earth program, version $6.0^{41}$. The correlation between genetic distance (Fst) and geographical distance was analyzed by the Pearson correlation test.

\section{RESULTS}

\section{Distribution and frequency of haplotypes}

Sequencing of Ny. neivai specimens from Doutor Camargo, Japira, Lobato and Porto Rico resulted in 80 sequences of $269 \mathrm{bp}$. The average composition of nucleotides was $40.1 \%$ thymine, $6.3 \%$ cytosine, $32.5 \%$ adenine and $21.1 \%$ guanine.

Table 1 shows the 27 haplotypes (H) found; 22 specimens were represented by only one haplotype (H1, H2, H3, H6, H9, H11, H12, H14, H15, H16, H18, H19, H20, H21, H22, H23, H24, H25, H26, H27). Haplotype H5 appeared in the largest number of specimens $(\mathrm{N}=33)$, followed by haplotype $\mathrm{H} 7(\mathrm{~N}=12)$, both of which were shared by all four populations. The third most common haplotype was H17, shared by five specimens from Japira and Lobato. Haplotypes H4, H10, H8 and H13 were present in Doutor Camargo and were shared with Porto Rico, Japira and Lobato. The largest number of exclusive haplotypes was detected in Doutor Camargo (H1, H2, H3, H6, H9, H11, H12, H14 and H15), followed by Lobato (H19, H20, H21, H22 and H23), Porto Rico (H24, H25, H26 and H27) and Japira (H16 and H18).

Table 2 shows the 28 polymorphic sites ( $\mathrm{S}$ ), a haplotype diversity $(\mathrm{Hd})$ of 0.80696 and a nucleotide diversity $(\mathrm{Pi})$ of 0.00567. Sandflies from Doutor Camargo and Lobato showed the largest number of haplotypes $(\mathrm{H})$, the greatest haplotype diversity (Hd), the highest nucleotide diversity (Pi), and the largest number of polymorphic sites (S). The highest number of single variations (singletons) was observed in the population from Doutor Camargo (19), followed by Lobato (7), Porto Rico (3) and Japira (3). Tajima's test was significant in Doutor Camargo.

Table 3 shows that $\mathrm{H} 12$ had the largest number of nucleotide mutation sites $(3,21,108,114,189,195,222$ and 267). The majority of haplotypes were distinct in sandflies by only two nucleotide sites. H4 and $\mathrm{H} 17$ differed in only one site (position 267) as did H10 and H20 (position 246).
Table 1 - Haplotype distribution of Nyssomyia neivaipopulations in the municipalities of Doutor Camargo, Japira, Lobato and Porto Rico, State of Paraná, Brazil.

\begin{tabular}{cccccc}
\hline $\begin{array}{c}\text { Haplotypes/ } \\
\text { Municipality }\end{array}$ & $\mathrm{D}$ & $\mathrm{J}$ & $\mathrm{L}$ & $\mathrm{P}$ & $\begin{array}{c}\text { Total of } \\
\text { specimens }\end{array}$ \\
\hline $\mathrm{H} 1$ & 1 & 0 & 0 & 0 & 1 \\
$\mathrm{H} 2$ & 1 & 0 & 0 & 0 & 1 \\
H3 & 1 & 0 & 0 & 0 & 1 \\
H4 & 1 & 0 & 0 & 1 & 2 \\
H5 & 5 & 11 & 6 & 11 & 33 \\
H6 & 1 & 0 & 0 & 0 & 1 \\
H7 & 2 & 4 & 4 & 2 & 12 \\
H8 & 1 & 0 & 1 & 0 & 2 \\
H9 & 1 & 0 & 0 & 0 & 1 \\
H10 & 1 & 1 & 0 & 0 & 2 \\
H11 & 1 & 0 & 0 & 0 & 1 \\
H12 & 1 & 0 & 0 & 0 & 1 \\
H13 & 1 & 0 & 1 & 0 & 2 \\
H14 & 1 & 0 & 0 & 0 & 1 \\
H15 & 1 & 0 & 0 & 0 & 1 \\
H16 & 0 & 1 & 0 & 0 & 1 \\
H17 & 0 & 2 & 3 & 0 & 5 \\
H18 & 0 & 1 & 0 & 0 & 1 \\
H19 & 0 & 0 & 1 & 0 & 1 \\
H20 & 0 & 0 & 1 & 0 & 1 \\
H21 & 0 & 0 & 1 & 0 & 1 \\
H22 & 0 & 0 & 1 & 0 & 1 \\
H23 & 0 & 0 & 1 & 0 & 1 \\
H24 & 0 & 0 & 0 & 2 & 2 \\
H25 & 0 & 0 & 0 & 2 & 2 \\
H26 & 0 & 0 & 0 & 1 & 1 \\
H27 & 0 & 0 & 0 & 1 & 1 \\
\hline Dotal & 20 & 20 & 20 & 20 & 80 \\
\hline Camargo=(D), Japira=(J), Lobato=(L), Porto Rico=(P).
\end{tabular}

H4 and H5 differed in 2 sites (positions 201 and 267) as did $\mathrm{H} 7$ and $\mathrm{H} 8$ (positions 9 and 21).

The circle size was proportional to the number of individuals found in each haplotype (Figure 2). The haplotype network has shown ancestrality among $N y$. neivai populations, and probably the haplotype $\mathrm{H} 5$ has a close genetic relationship with other haplotypes because of its 7 derived groups, including exclusive haplotypes from Doutor Camargo (H1, H2, H14, H15), Lobato (H19, H20, H21, H23) and Porto Rico (H24, H25, H26). H7 has originated exclusively haplotypes from Japira (H16, H18), Doutor Camargo (H11) and Lobato (H22). 
Table 2 - Estimated genetic differentiation of the mitochondrial NDH4 gene in Nyssomyia neivai populations for the municipalities of Doutor Camargo, Japira, Lobato and Porto Rico, State of Paraná, Brazil.

\begin{tabular}{lccccc}
\hline Genetic differentiation & $\mathrm{D}$ & $\mathrm{J}$ & $\mathrm{L}$ & $\mathrm{P}$ & Total \\
\hline No. of specimens $(\mathrm{n})$ & 20 & 20 & 20 & 20 & 80 \\
No. of haplotypes $(\mathrm{H})$ & 15 & 6 & 10 & 7 & 27 \\
Haplotype diversity (Hd) & 0,94211 & 0,67368 & 0,87368 & 0,69474 & 0,80696 \\
Mean of nucleotide differences $(\mathrm{K})$ & 2,76842 & 0,93168 & 1,36316 & 1,05789 & 1,52468 \\
Nucleotide diversity (Pi) & 0,01040 & 0,00346 & 0,00509 & 0,00395 & 0,00567 \\
No. of polymorphic sites (S) & 22 & 5 & 9 & 7 & 28 \\
Single variations (singletons) & 19 & 3 & 7 & 3 & 32 \\
Tajima's Test & $-2,20329^{*}$ & $-1,03729$ & $-1,59103$ & $-1,52506$ & $-2,37086$ \\
\hline
\end{tabular}

Doutor Camargo=(D), Japira $=(J)$, Lobato $=(L)$ e Porto Rico $=(P)$. Tajima's D: * $p<0.01$.

Table 3 - Variable sites observed in 27 haplotypes of NDH4 gene of mitochondrial DNA of Nyssomyia neivai from municipalities of Doutor Camargo, Japira, Lobato, and Porto Rico, State of Paraná, Brazil.

\begin{tabular}{|c|c|c|c|c|c|c|c|c|c|c|c|c|c|c|c|c|c|c|c|c|c|c|c|c|c|c|c|c|c|c|c|c|}
\hline \multirow[t]{4}{*}{ Haplotypes } & \multicolumn{32}{|c|}{ Positions of mutations in nucleotides } \\
\hline & 0 & 0 & 0 & 0 & 0 & 0 & 0 & 0 & & & 0 & 0 & 1 & 1 & 1 & 1 & 1 & 1 & 1 & & 1 & 2 & 2 & 2 & 2 & 2 & 2 & & & 2 & 2 & \\
\hline & 0 & 0 & 2 & 2 & 3 & 4 & 6 & 7 & & & 8 & 8 & 0 & 0 & 1 & 2 & 6 & 7 & $\varepsilon$ & & 9 & 0 & 0 & 1 & 2 & 2 & 4 & & & 6 & 6 & \\
\hline & 3 & 9 & 1 & 4 & 0 & 1 & 9 & 2 & & & 2 & 7 & 5 & 8 & 4 & 6 & 5 & 1 & s & & 5 & 1 & 5 & 9 & 2 & 8 & 6 & & & 4 & 7 & \\
\hline $\mathrm{H} 1$ & $G$ & G & $\bar{G}$ & $G$ & A & $\mathrm{T}$ & $T$ & $A$ & & & $A$ & $A$ & $T$ & $T$ & $A$ & $A$ & $\mathrm{~T}$ & $\bar{A}$ & $\mathrm{~T}$ & & T & $A$ & $\mathrm{G}$ & $A$ & $C$ & $A$ & $A$ & & $T$ & A & $A$ & 1 \\
\hline $\mathrm{H} 2$ & . & . & . & . & . & . & . & . & & & C & & . & r. & . & . & . & . & & & & . & . & . & . & $G$ & . & & & . & $\mathrm{G}$ & 1 \\
\hline $\mathrm{H} 3$ & . & . & A & . & . & . & . & . & ( & & & & . & . & . & . & . & . & & & & . & . & C & . & . & . & & & . & $\mathrm{G}$ & 1 \\
\hline $\mathrm{H} 4$ & . & . & . & . & . & . & . & . & & & . & & . & . & . & . & . & . & & & . & $\mathrm{G}$ & . & . & . & . & . & & & . & . & 2 \\
\hline $\mathrm{H} 5$ & & . & . & . & 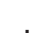 & . & . & 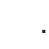 & & & 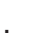 & & . & r. & . & . & . & 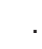 & & & . & . & . & . & . & . & 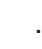 & & & . & $\mathrm{G}$ & 33 \\
\hline $\mathrm{H} 6$ & . & . & . & . & $\mathrm{G}$ & . & . & . & & & . & . & . & . & . & . & . & . & . & & . & . & . & . & . & . & & & & $\mathrm{G}$ & $\mathrm{G}$ & 1 \\
\hline $\mathrm{H} 7$ & . & . & A & . & . & . & . & . & & & . & . & . & . & . & . & . & . & & & . & . & . & . & . & . & 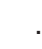 & & & . & $\mathrm{G}$ & 12 \\
\hline $\mathrm{H} 8$ & . & A & 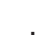 & . & . & . & . & . & & & . & . & . & . & . & . & . & . & & & . & . & . & . & . & . & . & & & . & $\mathrm{G}$ & 2 \\
\hline $\mathrm{H} 9$ & . & . & . & . & . & . & . & . & & & . & . & . & . & r. & . & . & $G$ & & & . & . & . & & $\mathrm{T}$ & . & . & & & . & $\mathrm{G}$ & 1 \\
\hline $\mathrm{H} 10$ & . & . & . & . & ${ }^{\circ}$ & . & . & . & & & . & r. & . & . & . & . & 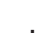 & . & & & $\cdot$ & . & . & . & & . & $G$ & & & . & $\mathrm{G}$ & 2 \\
\hline $\mathrm{H} 11$ & . & . & A & . & . & . & . & . & & & . & . & C & . & . & . & C & . & & & . & . & . & . & . & . & . & & & . & $\mathrm{G}$ & 1 \\
\hline $\mathrm{H} 12$ & $\mathrm{~T}$ & . & A & - & & . & . & . & & & . & $\cdot$ & . & C & $G$ & . & . & . & C & & $C$ & . & . & . & $\mathrm{T}$ & . & . & & & . & $\mathrm{G}$ & 1 \\
\hline $\mathrm{H} 13$ & . & . & . & A & 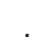 & . & . & . & & & . & . & . & . & . & . & . & . & & & . & . & . & . & . & . & . & & & . & $\mathrm{G}$ & 2 \\
\hline $\mathrm{H} 14$ & . & . & . & . & $\cdot$ & . & . & G & & & . & . & . & . & . & . & . & . & & & . & . & . & . & . & . & . & & & . & $\mathrm{G}$ & 1 \\
\hline $\mathrm{H} 15$ & A & . & . & . & & . & . & . & & & & . & . & 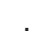 & 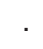 & . & . & . & & & . & . & . & . & $\cdot$ & . & 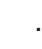 & & & . & $\mathrm{G}$ & 1 \\
\hline $\mathrm{H} 16$ & . & . & A & & . & . & G & 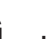 & & & . & . & . & . & . & . & . & . & & & . & . & . & & $\cdot$ & . & . & & & . & $\mathrm{G}$ & 1 \\
\hline $\mathrm{H} 17$ & . & . & . & . & ${ }^{\circ}$ & . & . & & & & & & . & . & 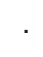 & . & 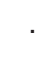 & . & & & & G & . & . & & . & . & & & . & $\mathrm{G}$ & 5 \\
\hline $\mathrm{H} 18$ & . & . & A & . & . & . & . & . & & & . & . & . & . & $\mathrm{T}$ & . & . & . & & & . & . & . & . & . & . & . & & & . & $\mathrm{G}$ & 1 \\
\hline $\mathrm{H} 19$ & . & . & . & . & . & C & . & . & & & . & & . & . & . & . & . & . & & & . & . & . & . & . & . & . & & & . & $\mathrm{G}$ & 1 \\
\hline $\mathrm{H} 20$ & . & & . & . & . & & . & & & & . & - & . & . & . & & 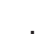 & . & & & . & . & . & . & . & & c & & & . & $\mathrm{G}$ & 1 \\
\hline $\mathrm{H} 21$ & . & . & . & . & . & . & . & . & & & . & . & . & . & . & $G$ & . & . & & & . & . & . & . & . & . & . & & & . & $\mathrm{G}$ & 1 \\
\hline $\mathrm{H} 22$ & $\cdot$ & . & A & . & . & . & . & . & & & & & . & . & . & . & 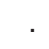 & . & & & & . & . & . & . & . & ${ }^{\circ}$ & & & . & $\mathrm{G}$ & 1 \\
\hline $\mathrm{H} 23$ & . & . & . & . & & . & . & & & & & $\mathrm{G}$ & . & & . & . & 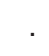 & . & & & & . & . & . & 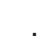 & . & . & & & . & $\mathrm{G}$ & 1 \\
\hline $\mathrm{H} 24$ & . & . & . & & . & . & . & & & & . & . & . & . & . & . & . & . & & & & . & A & & . & . & . & & & . & $\mathrm{G}$ & 2 \\
\hline $\mathrm{H} 25$ & . & . & . & . & 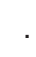 & . & . & & & & & ${ }^{\circ}$ & . & . & . & . & 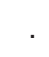 & . & & & & . & . & . & $\mathrm{T}$ & . & 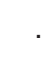 & & & . & $\mathrm{G}$ & 2 \\
\hline H26 & r. & . & . & . & . & . & . & & & & & & . & . & . & . & . & . & & & & . & . & . & $\cdot$ & . & . & & & G & $\mathrm{G}$ & 1 \\
\hline $\mathrm{H} 27$ & & . & . & . & i & . & . & & & & & & . & & . & . & & . & & & & G & & 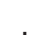 & & . & . & C & $C$ & . & $\mathrm{G}$ & 1 \\
\hline
\end{tabular}




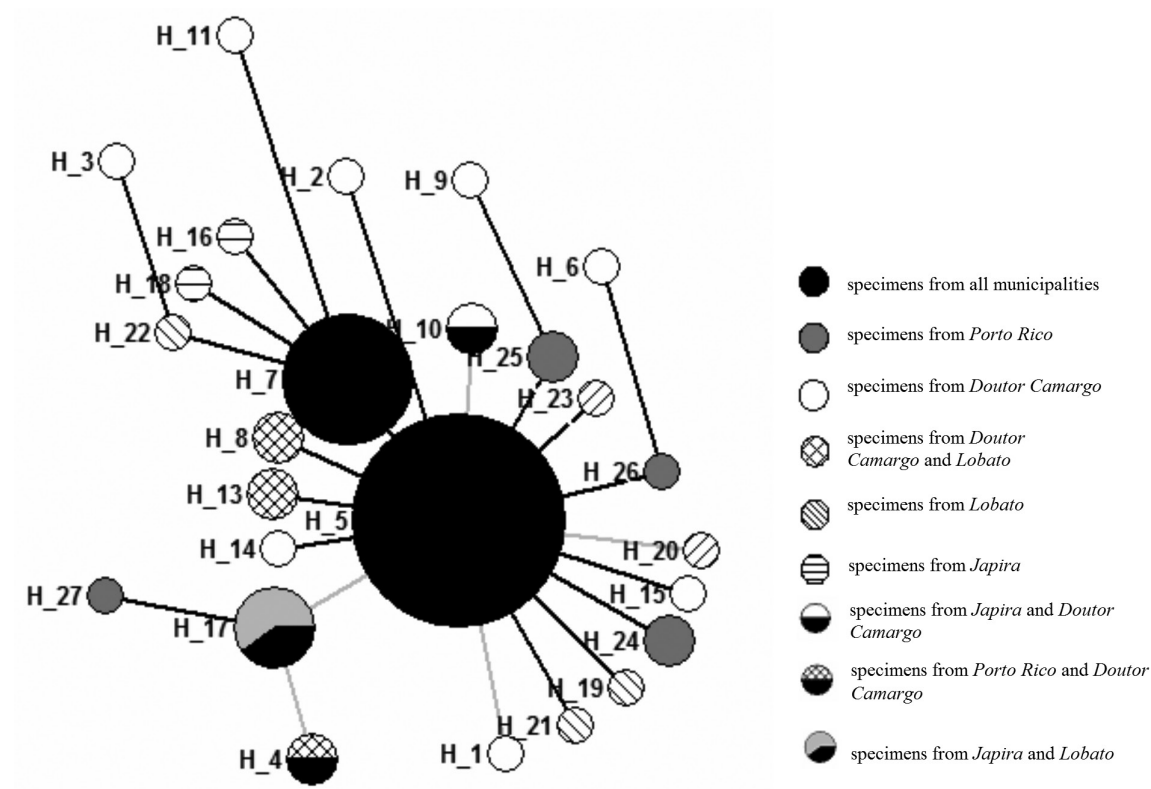

Figure 2 - Haplotype network of Nyssomyia neivai populations from municipalities of Doutor Camargo, Japira, Lobato, and Porto Rico, State of Paraná, Brazil.

\section{Analysis by means of dendrograms}

The dendrograms showed a strong similarity between individuals of $N y$. neivai populations from the four municipalities. The dendrogram branches were clearly defined and form a single group, even in Doutor Camargo and Lobato, which had the highest haplotype diversity, showing a low interspecific genetic variability among $\mathrm{Ny}$. neivai specimens from each locality (Figure 3 ).

\section{Genetic variation among populations}

Table 4 shows that the largest genetic distance (Fst) occurred between Japira and Porto Rico populations ( $F s t=0.02477)$, and the lowest between Doutor Camargo and Porto Rico ( $\mathrm{Fst}=-0.00428$ ). The number of nucleotide substitutions per site (Dxy) was the highest in Doutor Camargo and Lobato (Dxy=0.00759 and $\mathrm{Da}=-0.00009$ ) and the lowest in Japira and Porto Rico (Dxy=0.00379 and $\mathrm{Da}=0.00009$ ). Ny. neivai populations from Japira and Lobato showed an intense gene flow (39.64). The lowest gene flow (12.60) occurred between Japira and Porto Rico populations.

The Pearson correlation test between genetic distance (Fst) and geographical distance (Km) of populations from the four municipalities showed that there was no correlation between these two factors $(p=0.2246)$.

\section{DISCUSSION}

A total of 27 haplotypes of the $\mathrm{NDH} 4$ gene were detected from 80 female $N y$. neivai. This number of haplotypes is similar to that detected in another study of the $\mathrm{NDH} 4$ gene of $\mathrm{Lu}$. longipalpis populations ${ }^{26}$. Thymine and adenine were the most frequent, followed by guanine and cytosine, as also detected by Soto et al. ${ }^{26}$ who sequenced the $\mathrm{NDH} 4$ gene of mtDNA from 46 specimens of Lu. longipalpis.

$\mathrm{H} 5$, with 33 specimens, and $\mathrm{H} 7$, with 12 , were the most frequent haplotypes and the only ones present in all four populations. Ribolla et al. ${ }^{15}$ detected 13 haplotypes by analyzing mtDNA of 133 specimens of Lu. longipalpis and seven of $L u$. cruzi, and found a major haplotype (H2) composed of 111 individuals that represented $89 \%$ of three populations of the State of São Paulo, $90 \%$ of two populations of the State of Mato Grosso do Sul, and 38\% of one population of the State of Piauí. Arrivillaga et al..$^{21}$ detected 18 haplotypes in 343 Lu. longipalpis specimens collected in 12 localities of 5 countries (Brazil, Costa Rica, Colombia, Honduras and Venezuela). They did not identify any common haplotype among these populations, probably due to the large geographical distance and possible reproductive isolation followed by a dispersal period, causing the separation of species.

The haplotype diversity observed in the NDH4 gene of Ny neivai is considered high (0.80696), although lower than that detected by Soto $e t a l .{ }^{26}$ for the same gene of $L u$. longipalpis. Depaquit et al. ${ }^{27}$ observed in 11 haplotypes of the NDH4 gene of Phlebotomus papatasi a greater diversity than that observed in the present study, indicating that diversity is independent of the number of haplotypes. Ribolla et al..$^{15}$ found higher diversities (0.672 and 0.545) in populations of Lu. longipalpis in Teresina (Piauí), with six exclusive haplotypes, and Araçatuba (São Paulo), with 


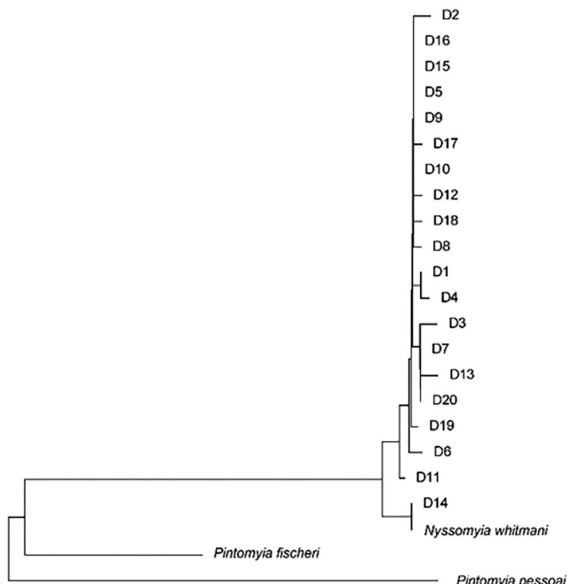

$\mathrm{A} \vdash \stackrel{0.05}{\stackrel{2}{2}}$

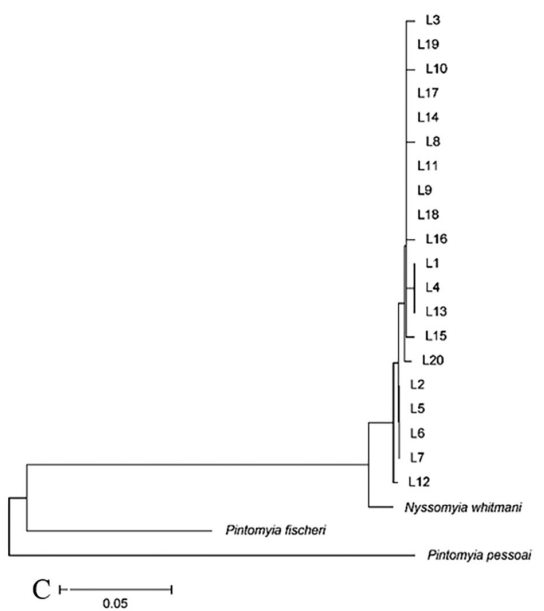

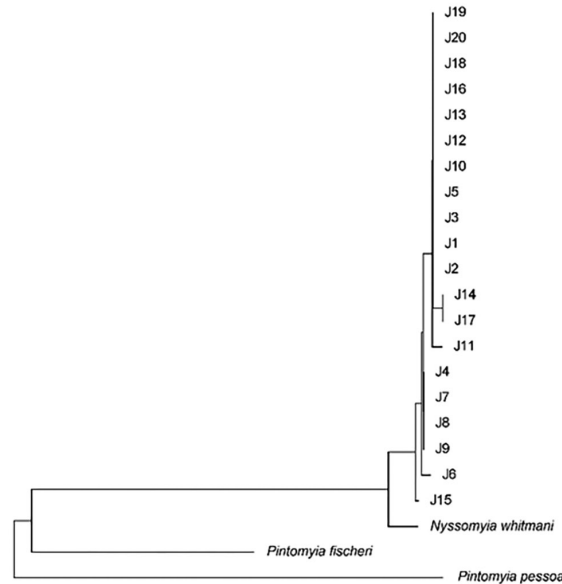

$\mathrm{B} \vdash \longrightarrow 0.05$

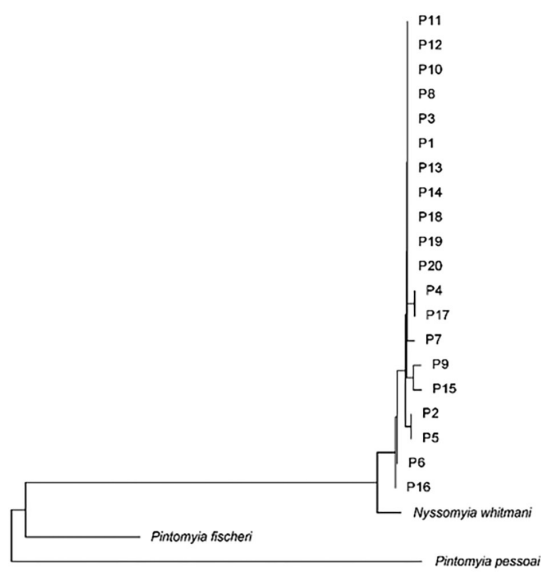

$\mathrm{D} \stackrel{0.05}{\longrightarrow}$

Figure 3 - Dendrogram of Nyssomyia neivai populations from (A) Doutor Camargo, (B) Japira, (C) Lobato, and (D) Porto Rico, State of Paraná, Brazil.

Table 4 - Genetic diferentiation (Fst) of Ny. neivai populations from municipalities of Doutor Camargo, Japira, Lobato, and Porto Rico, State of Paraná, Brazil.

\begin{tabular}{cccccc}
\hline Population & Fst & Dxy & Da & Nm & Distance $(\mathrm{Km})$ \\
\hline D e J & $-0,00955$ & 0,00681 & $-0,00007$ & 23,43 & 217 \\
D e L & $-0,01140$ & 0,00759 & $-0,00009$ & 24,53 & 61,5 \\
D e P & $-0,00428$ & 0,00708 & $-0,00003$ & 20,77 & 137 \\
J e L & $-0,02673$ & 0,00415 & $-0,00011$ & 39,64 & 206 \\
J e P & 0,02477 & 0,00379 & 0,00009 & 12,60 & 346 \\
L e P & 0,00777 & 0,00454 & 0,00004 & 16,43 & 138 \\
\hline
\end{tabular}

Doutor Camargo $=(D)$, Japira $=(J)$, Lobato $=(L)$, Porto Rico $=(P)$. Dxy= mean number of nucleotide substitutions per site between two populations, $\mathbf{D a}=$ total number of nucleotide substitutions between two populations, $\mathbf{N m}=$ number of migrants per generation.

five exclusive haplotypes, respectively.

Tajima's D neutrality tests were significant for all the samples $(p>0.05)$, indicating that the genetic polymorphism is according to the model of neutral mutations, excepting for the population from Doutor Camargo.

Genetic diversity varied among these four populations.
Sandflies from Doutor Camargo had higher genetic diversity than those collected in the other municipalities. This probably occurred because of constant anthropic changes that happened in the environment during the first half of the twentieth century ${ }^{42}$, mainly after 1998 , when efforts to control these insects began ${ }^{12,31}$. 
In Lobato, where the second-highest diversity was found, anthropic changes have been also constantly occurring, although less pronounced than in Doutor Camargo ${ }^{7}$. In contrast, the lowest haplotype diversity of Ny. neivai occurred in Japira and Porto Rico, where anthropic changes have been less intense than in Doutor Camargo and Lobato (Teodoro, personal communication). In municipalities where $N y$. neivai populations showed high genetic diversities, Monteiro et al. ${ }^{43}$ found increased incidences of LT.

The haplotype network demonstrated that there is a sequence of ancestry between haplotypes, evidencing that $\mathrm{H} 5$ has a genetic relationship with a large number of haplotypes, as seven groups of haplotypes were derived from $\mathrm{H} 5$.

The dendrograms show that the interspecific genetic variability is rather low in the populations of $\mathrm{Ny}$. neivai from these municipalities. Balbino ${ }^{24}$ found a moderate genetic divergence among populations of Lu. longipalpis in seven municipalities in Northeastern Brazil, while, Souza et al. ${ }^{20}$ found that $N y$. whitmani populations of four localities in the municipality of Corte de Pedra, State of Bahia, were more homogeneous than sandfly populations of Ilhéus (Bahia), Serra de Baturité (Ceará), and Martin Campos (Minas Gerais).

In the present study, the greatest genetic distance occurred between populations of Japira and Porto Rico ( Fst $=0.02477)$, as well as the lowest gene flow $(\mathrm{Nm}=12.60)$ and the lowest number of nucleotide substitutions per site (Dxy=0.00379). Geographical distance is a possible barrier between these municipalities, blocking haplotype sharing and suggesting the hypothesis that the genetic isolation between these two populations may reflect the geographical distance $(346 \mathrm{~km})$ between the two municipalities. Soto et $a .^{26}$ found that gene flow among populations of Guatemala and Honduras was almost nonexistent, because of mountains that act as geographical barrier between the two countries, hampering the haplotype sharing. However, populations of $\mathrm{Lu}$. longipalpis from Costa Rica and Honduras are genetically similar despite a geographical distance that is greater than that between Honduras and Guatemala ${ }^{26}$. It is noteworthy that most of Nicaragua, which is located between Costa Rica and Honduras, lies at altitudes less than $500 \mathrm{~m}$.

Ribolla et al..$^{15}$ studied populations of Lu. longipalpis in municipalities in the States of São Paulo, Mato Grosso do Sul and Piauí, and reported that gene flow occurs independent of the geographical distance. Populations of Ny. neivai from Doutor Camargo and Lobato are closer and share more haplotypes; however, there was no significant correlation between genetic $(\mathrm{Fst}=-0.01140)$ and geographical distances. Local and independent factors can favor the diversity of $N y$. neivai in each locality.

Sandflies in Doutor Camargo municipality showed the highest haplotype diversity and the largest number of exclusive haplotypes. Only the Ny. neivai population of Doutor Camargo shares haplotypes with populations from Lobato, Japira and Porto Rico. The largest genetic and geographic distances, and the lowest gene flow were found between Japira and Porto Rico; however, the dendrograms showed that there is interspecific homogeneity between the specimens from populations of these municipalities. Anthropic and natural environmental changes and geographical barriers are important and may be reflected in the genetic diversity of $N y$. neivai populations.

\section{ACKNOWLEDGEMENTS}

To the Coordenação de Aperfeiçoamento de Pessoal de Nivel Superior (CAPES) and the Conselho Nacional de Pesquisa e Desenvolvimento Científico ( $\mathrm{CNPq}$ Proc. 410550/2006-0) for the financial support. To the epidemiology officers José Luiz Filho, José do Parto dos Santos and Valmir Ortiz da Silva of the Serviço de Vigilância da Saúde of the Ministério da Saúde, Núcleo de Entomologia de Porto Rico, State of Paraná, for their assistance in collecting sandflies.

\section{REFERENCES}

1. World Health Organization. Leishmaniasis: situation and trends. [cited 2016 Mar 04]. Avaailable from: http://www.who.int/ gho/neglected_diseases/leishmaniasis/en/.

2. Brasil. Ministério da Saúde. Casos de leishmaniose tegumentar americana: Brasil, grandes regiões e unidades federadas, 1990 a 2013. [cited 2016 Jan 18]. Available from: http://goo.gl/ XL8xNM.

3. Galati EA. Morfologia e taxonomia. In: Rangel EF, Lainson R, organizadores. Flebotomíneos do Brasil. Rio de Janeiro: Fiocruz; 2003. p. 23-51.

4. Rangel EF, Lainson R. Proven and putative vectors of American cutaneous leishmaniasis in Brazil: aspects of their biology and vectorial competence. Mem Inst Oswaldo Cruz. 2009;104:93754.

5. Membrive NA, Rodrigues G, Membrive U, Monteiro WM, Neitzke HC, Lonardoni MVC, et al. Flebotomíneos de municípios do norte do Estado do Paraná, sul do Brasil. Entomol Vectores. 2004; 11:673-80.

6. Silva AM, Camargo NJ, Santos DR, Massafera R, Ferreira AC, Postai C, et al. Diversidade, distribuição e abundância de flebotomíneos (Díptera: Psychodidae) no Paraná. Neotrop Entomol. 2008;37:209-25. 
7. Teodoro U, Santos DR, Santos AR, Oliveira O, Poiani LP, Silva AM, et al. Informações preliminares sobre flebotomíneos do norte do Paraná. Rev Saúde Pública. 2006;40:327-30.

8. Teodoro U, Santos DR, Silva AM, Massafera R, Imazu LE, Monteiro WM, et al. Fauna de flebotomíneos em municípios do norte pioneiro do Estado do Paraná, Brasil. Rev Patol Trop. 2010;39:322-30.

9. Marcondes CB. A redescription of Lutzomyia (Nyssomyia) intermedia (Lutz e Neivai, 1912), and ressurrection of L. neivai (Pinto, 1926) (Diptera, Psychodidae, Phlebotominae). Mem Inst Oswaldo Cruz. 1996;91:457-62.

10. Marcondes CB, Lozovei AL, Vilela JH. Distribuição geográfica de flebotomíneos do complexo Lutzomyia intermedia (Lutz \& Neivai, 1912) (Diptera, Psychodidae). Rev Soc Bras Med Trop. 1998;31:51-8.

11. Teodoro U, Silveira TG, Santos DR, Santos ES, Santos AR, Oliveira $\mathrm{O}$, et al. Freqüência da fauna de flebotomíneos no domicílio e em abrigos de animais domésticos no peridomicílio, nos municípios de Cianorte e Doutor Camargo, Estado do Paraná, Brasil. Rev Patol Trop. 2001;30:209-23.

12. Teodoro U, Silveira TG, Santos DR, Santos ES, Santos AR, Oliveira $\mathrm{O}$, et al. Influência da reorganização, da limpeza do peridomicílio e a da desinsetização de edificações na densidade populacional de flebotomíneos no Município de Doutor Camargo, Estado do Paraná, Brasil. Cad Saúde Pública. 2003;19:1801-13.

13. Teodoro U, Santos DR, Santos AR, Oliveira O, Poiani LP, Kuhl JB, et al. Avaliação de medidas de controle de flebotomíneos no norte do Estado do Paraná, Brasil. Cad Saúde Pública. 2007;23:2597-604

14. Andrade Filho JD, Galati EA, Falcão AL. Nyssomyia intermedia (Lutz \& Neiva, 1912) and Nyssomyia neivai (Pinto, 1926) (Diptera, Psychodidae, Phlebotominae) geographica distribution and epidemiological importance. Mem Inst Oswaldo Cruz. 2007;102:481-7.

15. Ribolla PE, Gushi LT, Cruz MS, Costa CH, Costa DL, Lima Júnior MS, et al. Leishmania infantum genetic diversity and Lutzomyia longipalpis mitochondrial haplotypes in Brazil. Biomed Res Int. 2016;2016: 9249217

16. Spanos L, Koutroumbas G, Kotsyfakis M, Louis C. The mitochondrial genome of the mediterranean fruit fly, Ceratitis capitata. Insect Mol Biol. 2000;9:139-44.

17. Avise JC. Molecular markers, natural history and evolution. New York: Chapman and Hall; 1994.

18. Meneses CR, Cupolillo E, Monteiro F, Rangel EF. Microgeographical variation among male populations of the sandfly, Lutzomyia (Nyssomyia) intermedia, from an endemic area of American cutaneous leishmaniasis in the state of Rio de Janeiro, Brazil. Med Vet Entomol. 2005;19:38-47.

19. Rocha LS, Falqueto A, Santos CB, Grimaldi G Jr, Cupolillo E. Genetic structure of Lutzomyia (Nyssomyia) intermedia populations from two ecologic regions in Brazil where transmission of Leishmania (Viannia) Braziliensis reflects distinct eco-epidemiologic features. Am J Trop Med Hyg. 2007;76:559-65.

20. Souza CM, Fortes-Dias CL, Linardi PM, Dias ES. Phenetic studies on randomly amplified polymorphic DNA-polymerase chain reaction-variability of four geographical populations of Lutzomyia whitmani (Diptera: Psychodidae) in Brazil. Rev Soc Bras Med Trop. 2004;37:148-53.

21. Arrivillaga JC, Norris DE, Feliciangeli MD, Lanzaro GC. Phylogeography of the neotropical sand fly Lutzomyia longipalpis inferred from mitochondrial DNA sequences. Infect Genet Evol. 2002;2:83-95.

22. Marcondes CB, Day JC, Ready PD. Introgression between Lutzomyia intermedia and both Lu.neivai and Lu.whitmani and their roles as vectors of Leishmania braziliensis. Trans $\mathrm{R}$ Soc Trop Med Hyg. 1997;91:725-6.

23. Mazzoni CJ, Araki AS, Ferreira GE, Azevedo RV, Barbujani G, Peixoto AA. Multilocus analysis of introgression between two sand fly vectors of leishmaniasis. BMC Evol Biol. 2008;8:141.

24. Queiroz Balbino V, Coutinho-Abreu IV, Sonoda IV, Melo MA, Andrade PP, Castro JA, et al. Genetic structure of natural populations of the sand fly Lutzomyia longipalpis (Diptera: Psychodidae) from the Brazilian northeastern region. Acta Trop. 2006;98:15-24.

25. Ready PD, Day JC, Souza AA, Rangel EF, Davies CR. Mitochondrial DNA characterization of populations of Lutzomyia whitmani (Diptera: Psychodidae) incriminated in the peri-domestic and silvatic transmission of Leishmania species in Brasil. Bull Entomol Res. 1997;87:187-95.

26. Soto SI, Lehmann T, Rowton ED, Vélez BI, Porter CH. Speciation and population structure in the morphospecies Lutzomyia longipalpis (Lutz \& Neiva) as derived from the mitochondrial ND4 gene. Mol Phylogenet Evol. 2001;18:84-93.

27. Depaquit J, Lienard E, Verzeaux-Griffon A, Ferté H, Bounamous A, Gantier JC, et al. Molecular homogeneity in diverse geographical populations of Phlebotomus papatasi (Diptera, Psychodidae) inferred from ND4 mtDNA and ITS2 rDNA epidemiological consequences. Infect Genet Evol. 2008;8:159-70.

28. Hamarsheh O, Presher W, Yaghoobi-Ershadi MR, Amro A, Jawabreh AL, Sawalha S, et al. Population structure and geographical subdivision of the Leishmania major vector Phlebotomus papatasi as revealed by microsatellite variation. Med Vet Entomol. 2009;23:69-77.

29. Latrofa MS, Dantas-Torres F, Weigl S, Tarallo VD, Parisi A, Traversa D, et al. Multilocus molecular and phylogenetic analysis of phebotomine sand flies (Diptera: Psychodidae) from southern Italy. Acta Trop. 2011;119:91-8.

30. Corradini FA, Stevaux JC, Fachini MP. Geomorfologia e distribuição da vegetação ripária na ilha Mutum Rio Paraná PR/MS. Geociências. 2008;27:345-54. 
31. Reinhold-Castro KR, Scodro RB, Dias-Sversutti AC, Neitzke HC, Rossi RM, Kuhl JB, et al. Avaliação de medidas de controle de flebotomíneos. Rev Soc Bras Med Trop. 2008;41:269-76.

32. Loxdale HD, Lushai G. Molecular markers in entomology. Bull Entomol Res. 1998:88:577-600.

33. Gorrochotegui-Escalante N, Munoz ML, Fernandez-Salas I, Beaty BJ, Black WC 4th. Genetic isolation by distance among Aedes aegypti populations along the northeastern coast of Mexico. Am J Trop Med Hyg. 2000;62:200-9.

34. Paduan KS, Ribolla PE. Mitochondrial DNA polymorphism and heteroplasmy in populations of Aedes aegypti in Brazil. J Med Entomol. 2008;45:59-67.

35. Staden R. The Staden sequence analysis package. Mol Biotechnol. 1996;5:233-41.

36. Thompson JD, Gibson TJ, Plewniak F, Jeanmougin F, Higgins DG. The Clustal_X windows interface flexible strategies for multiple sequence alignment aided by quality analysis tools. Nucleic Acids Res. 1997;25:4876-82.

37. Tamura K, Peterson D, Peterson N, Stecher G, Nei M, Kumar S. MEGA5: molecular evolutionary genetics analysis using maximum likelihood, evolutionary distance, and maximum parsimony methods. Mol Biol Evol. 2011;28:2731-9.
38. Nei M. Evolution of human races at the gene level. In: BonneTamir B, Cohen T, Goodman RM, editors. Human genetics. Part A: The unfolding genome. New York: Alan R. Liss; 1982. p.167-81.

39. Librado P, Rozas J. DnaSP v5: a software for comprehensive analysis of DNA polymorphism data. Bioinformatics. 2009;25:1451-2.

40. Tajima F. Statistical method for testing the neutral mutation hypothesis by DNA polymorphism. Genetics. 1989;123:58595 .

41. Google. Google Earth. [cited 2015 Feb 16]. Available from: http:// www.google.com/intl/pt-PT/earth/index.html

42. Monteiro WM, Neitzke HC, Lonardoni MV, Silveira TG, Ferreira ME, Teodoro U. Geographic distribution and epidemiological features of American tegumentary leishmaniasis in old rural settlements in Paraná State, Southern Brazil. Cad Saúde Pública. 2008;24:1291-303.

43. Monteiro WM, Neitzke HC, Silveira TG, Lonardoni MV, Teodoro U, Ferreira ME. Pólos de produção de leishamaniose tegumentar americana no norte do estado do Paraná, Brasil. Cad Saúde Pública. 2009;25:1083-92. 